\title{
Differences in seasonal price patterns among second home rentals and hotels: empirical evidence and practical implications
}

\author{
Albert SAló
}

ESADE, Research Group in Tourism Management (GRUGET), Av. de la Torre Blanca 59, E-08172 Sant Cugat del Vallès, Spain. E-mail: albert.salo@esade.edu.

(Corresponding author.)

\section{ANNA GARRIGA}

Department of Economics, Universitat de Girona, Facultat de Ciències Econòmiques $i$ Empresarials, Campus Montilivi, 17071 Girona, Spain. E-mail: anna.garriga@udg.edu.

\section{RICARD RIGALL-I-TORRENT}

Department of Economics, Universitat de Girona, Facultat de Ciències Econòmiques i Empresarials, Campus Montilivi, 17071 Girona, Spain. E-mail: ricard.rigall@udg.edu.

\section{MAR VILA}

ESADE, Research Group in Tourism Management (GRUGET), Av. Pedralbes 60-62, E-08034 Barcelona, Spain.E-mail:marvila@esade.edu.

\section{JOSEP M. SAYERAS}

ESADE, Research Group in Tourism Management (GRUGET), Av. Pedralbes 60-62, E-08034 Barcelona, Spain.E-mail: E-mail: josepm.sayeras@esade.edu.

Hotels and second home rentals are two of the most important tourist accommodation options in Spain. In terms of seasonality, almost all previous studies have analysed tourism demand from the point of view either of total arrivals or the number of tourists lodged in a single accommodation type (hotels, rural accommodation, etc). However, there are no studies focusing on price seasonality or comparing seasonality among different accommodation types. By using seasonality indicators and a price index constructed by means of

The authors would like to thank the participants at the 6th Annual International Conference on Tourism, held on 1-4 July 2010 in Athens and organized by ATINER (Athens Institute for Education and Research), for their valuable comments. We also thank Modest Fluvià for his valuable comments and Josep-Maria Espinet for providing us with access to the hotel database used in this paper. 
hedonic methods, this paper aims to shed some light on seasonal pricing patterns among second home rentals and hotels. The paper relies on a 2004 database of 144 hotels and 1,002 apartments on the Costa Brava (northeast Spain). The results show that prices for second home rentals display a smoother seasonal pattern than hotels due to reduced price differences between shoulder (May and October) and peak periods (August).

Keywords: seasonality, second homes; hotels; prices; Costa Brava

Different strategies have been deployed in the tourism and hospitality industries to smooth the common seasonal patterns observed in these sectors. The ultimate goal of such strategies has been to maintain tourist demand constant throughout the year in areas where climate plays a key role and creates a strong limitation to, for example, sun-and-beach destinations along the Mediterranean (Butler, 2001; Jang, 2004; Yacoumis, 1980; SooCheong, 2004).

Despite a wide range of seasonality references from the demand point of view, there is little research on the supply perspective. Moreover, considering the variety of accommodation options available today, it is useful to distinguish the seasonality pattern by type of accommodation, since hotels, second home rentals, rural accommodation and bed and breakfasts, for instance, might display quite different seasonal patterns. It is also worthwhile to ascertain what strategy accommodation managers opt for in terms of their pricing policy to increase this demand.

This paper therefore analyses seasonality in terms of prices for hotels and second home rentals. For this purpose, we use data collected from brochures regarding accommodation on the Costa Brava (northeast Spain), where hotels and second home rentals are the main accommodation options for tourists. Specifically, second homes represent more than $50 \%$ of the total beds available in the area (Saló and Garriga, 2011), a comparable figure to that in the overall accommodation tourist market.

The next section reviews the main sources in the literature on seasonality. In the subsequent section we describe the data used and some tools that measure tourism seasonality, paving the way for the fourth section, which offers a hedonic analysis of hotel and second home prices. The penultimate section includes discussion points and possible strategies for managers and local policy makers. Finally, we offer our conclusions and suggest possible directions for future research.

\section{A review of the literature on tourism seasonality}

Policy makers and managers are usually greatly concerned about seasonality for several reasons, such as short business operating seasons, the under-utilization of capital assets, short-term employment or maintenance services, and product quality standards in the absence of long-term employment (Baum and Lundtorp, 2001). Also, some public services can be overused when both tourists and the local population share them. In order to overcome the problems associated with 
seasonality, firms try to offer tourists complementary services so that more are attracted during non-peak periods, thus avoiding the inconvenience of undiversified sun-and-beach destinations (Bar-on, 1999; Butler, 1994).

Most authors carry out a time series analysis of tourism demand (trends and cycles) and forecasting (Aguiló and Sastre, 1984; Fernández-Morales 2003; GilAlana et al, 2004; Guizzardi and Mazzocchi, 2010; Kulendran and Wong, 2005; Rosselló et al, 2004). These and other methodologies have been used, for example, to analyse seasonality patterns (Lundtorp, 2001; Sutcliffe and Sinclair, 1980; Wanhill, 1980) and have been applied in different regions like Spain (Barke and France, 1986; González and Moral 1995, 1996; Pearce and Grimmeau, 1985; Mayorga-Toledano and Fernández-Morales, 2008), the object of study of this paper.

It is worth bearing in mind that rigid limitations arise when attempting to reduce seasonality. Some authors have mentioned climate and temperature as key factors to increase demand in sun-and-beach destinations like the Costa Brava in Spain. But there are also inflexible factors, such as set calendar schedules - public, school and bank holidays. The long summer holiday remains the largest limitation to reducing the seasonal concentration of tourists. In fact, long stays rather than short stays tend to occur during the peak season (Jeffrey and Barden, 2001). There is still a long tradition or inertia that leads workers to opt to take holidays in August, directly affecting seasonality in Mediterranean destinations.

On the other hand, this seasonality provides some benefits. Butler (2001) considers several advantages in social, environmental and economic terms. For example, the local population may value the existence of off-season months, without the heavy use of public services, encouraging a more sustainable environment and possibly balancing the overuse occurring during the peak season. In economic terms, tourism can be an employment option in local areas like the Costa Brava, making the sector an alternative to complement jobs available during off-season periods. But tourism is also a temporary option for the unemployed from other economic sectors.

Unlike demand analyses, however, few studies examine the supply side, focusing on hotel quality (Capó Parrilla et al, 2007) and employment patterns (Ashworth and Thomas, 1999; Krakover, 2000). Similarly and despite having a wide range of research available on tourism seasonality, there are no crosssection analyses comparing patterns among different types of tourist accommodation. In this sense, there are global studies (number of tourists/ nights spent in all accommodation) or partial analyses for one sector, basically hotels (Fernández-Morales, 2003; Mayorga-Toledano and Fernández-Morales, 2008; Capó Parrilla et al, 2007) and rural accommodation (Albacete et al, 2007; Albadalejo and Díaz, 2005, 2009) in specific locations.

The role accommodation supply plays can be a factor influencing this seasonality. Yacoumis (1980) argues that controlling supply at levels below those of expected peak demand is an option to redistribute excess demand throughout the season and smooth seasonality cycles, thus affecting the final price market. In addition, Yacoumis raises an interesting debate about the consequences on final price when supply restrictions are imposed (for example, because of the seller's market power or due to a decrease in quality).

Also in terms of supply, Capó Parrilla et al (2007) show that greater quality 
in hotels (measured in terms of star rating) implies that they are open more. Proximity to urban areas and being well-connected in terms of transport also seem to lengthen opening periods. Cuccia and Rizzo (2011) analyse the effect of cultural events on seasonality patterns in several locations in Italy.

Albadalejo and Díaz (2005) present a methodology to match tourist profiles according to the different accommodation types offered, focusing on rural accommodation facilities in the region of Murcia (Spain). The authors remark on the need to take into account tourists' characteristics and preferences to promote suitable accommodation options in a concrete destination. Good market segmentation and matching demand preferences and supply characteristics could help to increase the occupancy rate, and also tackle the seasonality problem.

The same authors (Albadalejo and Díaz, 2009) use rural accommodation to match the tourist profile with different tourist accommodation options. It seems that income level, work status, typology of family unit, among other factors, are relevant and may influence the final price along with the period analysed.

Lundtorp et al (2001) underscore the variation in accommodation supply throughout the year on Bornholm Island. Interestingly, summer houses are most used as the accommodation type (49\% of the total) during off-season periods. During peak and shoulder seasons, however, hotels and summer houses have similar market shares (30-35\% of the total) on the island, and there is an increase in the use of campsites and caravans as accommodation options. The same authors discuss the role of cost structure and its relationship with seasonality patterns. High fixed costs for hotels in Bornholm and a lack of investment in them are seen as an entrance barrier. On the contrary, summer homes require less investment, most of them are individually owned, used by the owner and lent out to friends or leased out through an agency.

Another analysis of note within the accommodation sector is that of Koenig and Bischoff (2003), who analyse regional seasonal variations across different accommodation options (hotels, bed and breakfast, farmhouses and guest houses) in Wales. As an example, bed and breakfast establishments and farmhouses show a much sharper summer peak than guest houses, while a higher star category among hotels seems to stretch their occupancy rate over time (in line with the results of Capó Parrilla et al, 2007).

The same authors (Koenig and Bischoff, 2003) also reveal differences in seasonal patterns for concrete accommodation types because of their location in different towns. Here, we consider it relevant to extend our analysis to other accommodation segments from a policy making perspective, drawing appropriate policies for each sector. Despite the existence of some literature in the supply analysis of seasonality, there is no research on seasonality in terms of price. The next sections focus on this aspect.

\section{Data and measures of seasonality}

This paper attempts to shed light on the analysis of price seasonality and compares hotels and second home rentals. The first hypothesis we wish to test is: 
Hypothesis 1: Is there any significant difference in seasonality price patterns between hotels and second homes or, in general, does the accommodation industry follow the same pattern?

The idea is that there could be a significant difference in terms of price seasonality between them or, on the contrary, they may show similar trends because, in fact, tourists are lodged in the same geographical area.

In order to examine the hypothesis, we use a database of prices and characteristics built from various brochures belonging to different intermediaries offering hotel and second home rental accommodation in different municipalities on the Costa Brava from May to October. This period is when hotels are open and second homes are available and it includes shoulder and peak months. There are 144 hotels and 1,002 second home rentals in this database.

In order to have comparable data, we used the price per night on a weekly basis (based on a seven-day package according to the brochures). We chose a given week from every month (10-17 May; 21-28 June; 5-12 July; 2-9 August; 6-13 September; and 11-18 October) in order to obtain a perfect match between hotels and second homes. No shifts in supply accommodation arise during this period.

Table 1 shows the mean price per night of accommodation during the period studied. We must bear in mind that prices do not include discounts or specific offers in the brochures. As explained by Rigall-I-Torrent and Fluvià (2011), it is reasonable to assume that brochure prices reflect the 'expected' prices paid by tourists; that is, they are subject to deviations regarding the expected value.

In line with Lundtorp (2001), who provides a review of many measures of seasonality in tourism, we use three indicators to measure seasonality in terms of price. If $p_{1, a c}, \ldots, p_{i, a c}, \ldots, p_{6, a c}$ represent prices in period $i$ (where $I=1, \ldots, 6$ months) for each type of accommodation ac (whether hotels or second homes), $p_{a c}^{M A X}, p_{a c}^{M I N}$ are the maximum and minimum prices, respectively, while $\overline{p^{a c}}$ is the mean price. As such, the coefficient for the variation in prices for accommodation ac can be defined as follows:

$$
C V p_{a c}=\frac{\sqrt{\frac{1}{N} \sum_{n=1}^{N}\left(p_{i}^{a c}-\overline{p^{a c}}\right)^{2}}}{\overline{p^{a c}}}
$$

The seasonality ratio would thus be

$$
S R p_{a c}=\frac{p_{a c}^{M A X}}{\overline{p^{a c}}},
$$

and the ratio between the maximum price charged with regard to the minimum price would be

$$
\operatorname{Max} / \operatorname{Min} p_{a c}=\frac{p_{a c}^{M A X}}{p_{a c}^{M I N}} \text {. }
$$


Table 1. Mean price by season.

\begin{tabular}{llcccccc}
\hline & & May & June & July & August & September & October \\
\multirow{2}{*}{ Second homes } & & & & & & & \\
& Mean & 56.09 & 64.10 & 102.73 & 105.98 & 64.39 & 58.72 \\
& N & 990 & 1,000 & 1,001 & 1,002 & 1,000 & 976 \\
\multirow{4}{*}{ Hotels } & Std dev & 35.04 & 38.56 & 56.23 & 56.82 & 38.86 & 36.46 \\
& & & & & & & \\
& Mean & 28.81 & 39.61 & 50.47 & 63.25 & 40.55 & 28.59 \\
& N & 144 & 144 & 144 & 144 & 144 & 144 \\
& Std dev & 17.08 & 19.40 & 19.67 & 21.35 & 20.65 & 15.93 \\
\hline
\end{tabular}

Table 2. Seasonality price indicators.

\begin{tabular}{llccc}
\hline & & CV & SR & Max/Min \\
\multirow{2}{*}{ Second homes } & Mean & 0.32 & 1.44 & 2.04 \\
& N & 1,002 & 1,002 & 1,002 \\
& Std dev & 0.11 & 0.16 & 0.54 \\
Hotels & Mean & 0.35 & 2 & 2.43 \\
& N & 144 & 144 & 144 \\
& Std dev & 0.09 & 0.16 & 0.47 \\
\hline
\end{tabular}

Note: $\mathrm{CV}=$ coefficient of variation; $\mathrm{SR}=$ seasonality ratio; $\mathrm{Max} / \mathrm{Min}=$ maximum price over minimum price.

Table 3. One-way Anova test for seasonality price indicators.

\begin{tabular}{llccccc}
\hline & & $\begin{array}{c}\text { Sum of } \\
\text { squares }\end{array}$ & $\begin{array}{c}\text { Freedom } \\
\text { degrees }\end{array}$ & $\begin{array}{c}\text { Mean } \\
\text { squares }\end{array}$ & F & Significance \\
$\mathrm{CV} *$ accom & Between groups & 0.37 & 1.00 & 0.37 & 34.36 & 0.00 \\
& Within groups & 14.79 & $1,382.00$ & 0.01 & & \\
& Total & 15.16 & $1,383.00$ & & & \\
SR * accom & Between groups & 3.55 & 1.00 & 3.55 & 139.95 & 0.00 \\
& Within groups & 35.03 & $1,382.00$ & 0.03 & & \\
& Total & 38.58 & $1,383.00$ & & & \\
Max/Min * accom & Between groups & 42.97 & 1.00 & 42.97 & 156.06 & 0.00 \\
& Within groups & 380.51 & $1,382.00$ & 0.28 & & \\
& Total & 423.48 & $1,383.00$ & & & \\
\hline
\end{tabular}

Note: Accom = accommodation options (dummy variable: second homes or hotels). $\mathrm{CV}=$ coefficient of variation; $\mathrm{SR}=$ seasonality ratio; $\mathrm{Max} / \mathrm{Min}=$ maximum price over minimum price .

For all these indicators, the higher the value, the greater the seasonality. Results for these indicators are shown in Table 2. In addition, we carried out a oneway ANOVA test to distinguish whether seasonal patterns were statistically different for both types of accommodation.

In Table 3 we present the results for all three indicators when the significance level is $<0.01$; that is, when we can state that there are significant differences 
between hotels and second home rentals in terms of price seasonality. The results show that the coefficient of variation $(0.35$ versus 0.32$)$, the seasonality ratio ( 2 versus 1.44$)$ and the maximum price over the minimum price $(2.43$ versus 2.04) are always higher in hotels. According to these preliminary results, we can conclude that hotels are more seasonal than second homes in terms of price, no matter which indicator is analysed.

\section{Seasonality analysis: a hedonic price approach}

\section{Hypotheses to contrast}

In this section we want to analyse seasonality further in terms of price by adding the next hypotheses. Basically, we want to enhance the results obtained in the above section in order to identify implications for local policy makers and managers.

Hypothesis 2: There are other variables (for example, the services and quality offered by hotels andlor second homes) that may influence the results of Hypothesis 1. In a ceteris paribus context (controlling for other variables that also explain the price of an accommodation), what role does the variable 'time period' play in determining the final price?

Hypothesis 3: If second homes are less seasonal than hotels, how can we measure price differences in a month per month analysis?

\section{Model specification}

To contrast these hypotheses analysing in-depth seasonality implications, we require more specific tools - like the hedonic price technique. That technique allows us to enhance the results because it controls for different variables that also affect the final price in a ceteris paribus statistical analysis. Thus we overcome the limitations of analysing only variance as in the previous section.

Hedonic methods are based on the idea that some goods or services can be seen as a bundle of characteristics, and market price is assumed to be a function of their attributes. In other words, the contribution of every characteristic or attribute determines the final price that is set for a good or service. In addition, this technique is widely used in tourist markets. Since Sinclair et al's study (1990), the main goals have been to reveal the different attributes that have a significant effect on price in the accommodation industry. Another interesting issue is the effect of the commercialization channel on destinations, specifically tour operators (Sinclair et al, 1990; Espinet et al, 2003; Thrane, 2005; Haroutunian et al, 2005).

Rigall-I-Torrent and Fluvià $(2007,2011)$ use a theoretical model to find evidence of the effects of public goods and services on a tourist destination's hotel prices. They also create an index of private and public characteristics within locations. Similarly, there is literature regarding housing market studies (Bover and Velilla, 2002) and, more recently, regarding the second home rental market (Saló and Garriga, 2011). 
A hedonic price function can be considered as follows (Sinclair et al, 1990):

$$
P(A)=P\left(A_{1}, A_{2}, A_{3}, \ldots, A_{n}\right)
$$

Where $A_{i}$ is the quantity or value of $i$ th characteristic. In our case, the model used to run a regression on each accommodation type is as follows:

$$
\ln \operatorname{price}_{i t}^{a c}=f\left(c c_{i}, e c_{i}^{a c}, t_{i t} ; \beta\right)+\mu_{i t}
$$

We consider the subscripts, $i=1, \ldots, N t=1, \ldots, T$, where $i$ identifies each second home or hotel and $t$ the season selected. The superscript $a c$ is the type of accommodation (hotels or second homes). In addition, ln price $e_{i t}$ is the natural logarithm of the price, while $f(\cdot)$ is a linear function of the parameters and $c c_{i}$ are the common characteristics shared by hotels and second home rentals: common garden, car park, swimming pool, distance to the nearest beach and a star rating system. The variable $e_{i}^{a c}$ refers to the exclusive characteristics of each accommodation type.

Because hotels and second homes have different attributes, they have their own exclusive characteristics. For hotels $\left(e c_{i}^{a c}\right)$, this includes room service, outdoor and indoor sports facilities, entertainment activities, whether or not the building has been refurbished, whether the hotel is independent or part of a chain, and whether it is a hotel or an apart-hotel. Finally, we add an additional variable regarding the commercialization channel used: the tour operator responsible for the booking. In our case, five tour operators are considered for the Costa Brava - Rhodasol, TravelPlan, El Corte Inglés, Iberojet and Marsol (the last is used as the reference).

On the other hand, for second home rentals the exclusive characteristics $\left(e c_{i}^{a c}\right)$ are basically the number of rooms, the surface area, the terrace surface area, the type of home (apartment, detached or single-family home) and the availability of sea views. In this case, there is no variable concerning the commercialization channel because most of our data were collected from the brochures of a single intermediary with a high market share. In Spain, the second home rental market has a limited offering of intermediary brochures compared to those available for hotels. Table 4 summarizes the variables, descriptions and code names used.

Finally, $t_{i t}$ is the coding associated with the variable season. It refers to the effect of changes in the season over the final accommodation price. Price differences in May, June, July, September and October are compared to August (the reference period). This allows us to observe whether or not there are significant differences in price when comparing months. Finally, $\beta$ refers to all the coefficients obtained with the aforementioned variables.

All the aforementioned variables are attributes that affect the final price. We know that the period changes the final price of an accommodation offer. But a change in qualitative items, such as a swimming pool (having one or not), a common garden (having one or not) and distance to the beach (beachfront or two miles away), also changes the final price. Thus, hedonic regression is useful for isolating the change in price stemming from a change in a concrete attribute by controlling for the rest.

In econometric terms, in accordance with the approach commonly used in the literature, a semi-logarithmic specification has been chosen. This specification 
Table 4. Variables included in hedonic price models.

\begin{tabular}{|c|c|c|c|}
\hline Accommodation type & Variable & Coded name & Description \\
\hline Hotels, second homes & Distance to beach & beach distance & Beachfront or otherwise \\
\hline Hotels, second homes & Common garden & common garden & $\begin{array}{l}\text { Availability of outdoor, } \\
\text { common garden }\end{array}$ \\
\hline Hotels, second homes & Swimming pool & pool & Availability of swimming pool \\
\hline Hotels, second homes & Cark park & Cark park & Availability of car park \\
\hline \multirow[t]{5}{*}{ Hotels, second homes } & Star rating & $\begin{array}{l}\text { star } 1 \\
\text { (rf for second homes) }\end{array}$ & 1-star category \\
\hline & & star 2 & 2-star category \\
\hline & & star 3 (rf for hotels) & 3-star category \\
\hline & & star 4 & 4-star category \\
\hline & & star 5 & 5-star category \\
\hline \multirow[t]{6}{*}{ Hotels, second homes } & Season & May & May \\
\hline & & June & June \\
\hline & & July & July \\
\hline & & August (rf) & August \\
\hline & & September & September \\
\hline & & October & October \\
\hline Hotels & Room service & room service & Availability of room service \\
\hline Hotels & Outdoor sports & outdoor sports & Availability of outdoor sports \\
\hline Hotels & Entertainment & entertainment & Availability \\
\hline Hotels & Indoor sports & indoor sports & Apartment \\
\hline Hotels & Refurbished & refurbished & Availability of car park \\
\hline Hotels & Hotel type & hoteltype & Apart-hotel or hotel \\
\hline Hotels & Hotel management & chain\&indep & Hotel chain or independent \\
\hline \multirow[t]{5}{*}{ Hotels } & Tour operator & marsol (rf) & Marsol \\
\hline & & rhodasol & Rhodasol \\
\hline & & travelpl & TravelPlan \\
\hline & & corteing & El Corte Inglés \\
\hline & & iberojet & Iberojet \\
\hline Second homes & Rooms & rooms & Number of rooms \\
\hline Second homes & Sea views & sea views & Availability of sea views \\
\hline \multirow[t]{3}{*}{ Second homes } & House type & apartment & Apartment \\
\hline & & isolated house & Single-family home \\
\hline & & detached house (rf) & Detached house \\
\hline \multirow[t]{3}{*}{ Second homes } & Surface area & home area: $0-50 \mathrm{sm}(\mathrm{rf})$ & From 0 to 50 square metres \\
\hline & & home area: $50-100 \mathrm{sm}$ & From 51 to 100 square metres \\
\hline & Terrace surface area & $\begin{array}{l}\text { home area: } 101 \mathrm{sm}+ \\
\text { terrace: } 0-10 \mathrm{sm}(\mathrm{rf})\end{array}$ & $\begin{array}{l}\text { More than } 100 \text { square metres } \\
\text { From } 0 \text { to } 10 \text { square metres }\end{array}$ \\
\hline \multirow{2}{*}{ Second homes } & & terrace: $10-30 \mathrm{sm}$ & From 11 to 30 square metres \\
\hline & & terrace: $31 \mathrm{sm}+$ & More than 30 square metres \\
\hline
\end{tabular}

Note: (rf) is used as a reference in dummy variables in hedonic price models.

is appropriate when most of the independent variables are dummies. In this context, the coefficients associated with dummy variables need to transform to show the percentage effect over the dependent variable; that is, $e^{\beta}-1$ where $\beta$ is the coefficient obtained in the regression (Palmquist and Halverson, 1980). A stepwise regression is used where the final models included are those with the highest adjusted $R^{2}$. No multiplicative interactions have been introduced 
Table 5. Hedonic price model for hotels.

Hotel model

\section{Coefficient Std error $\quad p$-value $\quad$ VIF}

$\begin{array}{lrrrc}\text { Constant } & 3.987 & 0.031 & 0.000 & - \\ \text { beach distance } & 0.083 & 0.013 & 0.000 & 1.247 \\ \text { room service } & 0.137 & 0.017 & 0.000 & 1.783 \\ \text { common garden } & -0.022 & 0.020 & 0.249 & 1.088 \\ \text { pool } & -0.201 & 0.019 & 0.000 & 1.274 \\ \text { outdoor sports } & 0.159 & 0.012 & 0.000 & 1.184 \\ \text { car park } & 0.133 & 0.015 & 0.000 & 1.265 \\ \text { entertainment } & -0.076 & 0.011 & 0.000 & 1.262 \\ \text { indoor sports } & 0.065 & 0.011 & 0.000 & 1.248 \\ \text { refurbished } & -0.031 & 0.011 & 0.003 & 1.187 \\ \text { star 1 } & -0.173 & 0.031 & 0.000 & 1.445 \\ \text { star 2 } & -0.154 & 0.025 & 0.000 & 1.472 \\ \text { star 4 } & 0.555 & 0.015 & 0.000 & 1.255 \\ \text { star 5 } & 3.886 & 0.100 & 0.000 & 1.128 \\ \text { chain\&indep } & 0.103 & 0.013 & 0.000 & 1.196 \\ \text { hoteltype } & 0.197 & 0.027 & 0.000 & 1.071 \\ \text { rhodasol } & 0.032 & 0.014 & 0.028 & 1.347 \\ \text { travelpl } & -0.023 & 0.013 & 0.078 & 1.350 \\ \text { corteing } & 0.132 & 0.019 & 0.000 & 1.248 \\ \text { iberojet } & -0.062 & 0.015 & 0.000 & 1.311 \\ \text { May } & -0.569 & 0.017 & 0.000 & 1.667 \\ \text { June } & -0.398 & 0.017 & 0.000 & 1.667 \\ \text { July } & -0.212 & 0.017 & 0.000 & 1.667 \\ \text { September } & -0.388 & 0.017 & 0.000 & 1.667 \\ \text { October } & -0.569 & 0.017 & 0.000 & 1.667\end{array}$

Dependent variable: $\log$ (price)

$\mathrm{N}$

Adjusted- $R^{2}$

0.770

$\mathrm{F}$

320.43

$p$-value

0.000

Mean VIF

1.28

Max VIF

1.78

Durbin-Watson

0.84

showing multicollinearity problems in preliminary trials. The perturbation term $\mu_{i t}$ is normally distributed.

\section{Estimation and results}

Tables 5 and 6 show the main results of both regressions for hotels and second home rentals. The adjusted $R^{2}$ for both regressions is high (around 0.80). Most of the coefficients are individually significant at very high levels. In addition, the $p$-value in the F-test for the whole regression is less than 0.001. Finally there is no problem in terms of multicollinearity since the mean VIF (variance inflation factor) is 1.28 for hotels and 2.06 for second home rentals. In addition, the highest VIF, that is 3.88 , is remarkably lower than 10 . 
Table 6. Hedonic price model for second home rentals.

Second home model

\begin{tabular}{|c|c|c|c|c|}
\hline Coded name & Coefficient & Std error & $p$-value & VIF \\
\hline Constant & 5.829 & 0.033 & 0.000 & - \\
\hline rooms & 0.154 & 0.007 & 0.000 & 2.735 \\
\hline home area: $50-100 \mathrm{sm}$ & -0.005 & 0.014 & 0.749 & 2.116 \\
\hline home area: $101 \mathrm{sm}+$ & 0.085 & 0.024 & 0.001 & 3.880 \\
\hline terrace: $10-30 \mathrm{sm}$ & 0.008 & 0.013 & 0.536 & 1.483 \\
\hline terrace: $31 \mathrm{sm}+$ & 0.029 & 0.015 & 0.051 & 1.757 \\
\hline common garden & -0.028 & 0.012 & 0.023 & 1.554 \\
\hline isolated home & 0.111 & 0.019 & 0.000 & 3.037 \\
\hline apartment & -0.143 & 0.019 & 0.000 & 3.501 \\
\hline car park & -0.018 & 0.011 & 0.100 & 1.293 \\
\hline pool & 0.238 & 0.012 & 0.000 & 1.351 \\
\hline beach distance & 0.092 & 0.016 & 0.000 & 1.169 \\
\hline sea views & 0.115 & 0.011 & 0.000 & 1.225 \\
\hline star 2 & 0.091 & 0.019 & 0.000 & 3.187 \\
\hline star 3 & 0.328 & 0.021 & 0.000 & 3.347 \\
\hline star 4 & 1.478 & 0.049 & 0.000 & 1.295 \\
\hline May & -0.444 & 0.017 & 0.000 & 1.667 \\
\hline June & -0.392 & 0.017 & 0.000 & 1.667 \\
\hline July & -0.024 & 0.017 & 0.166 & 1.667 \\
\hline September & -0.364 & 0.017 & 0.000 & 1.667 \\
\hline October & -0.410 & 0.017 & 0.000 & 1.667 \\
\hline
\end{tabular}

Dependent variable: $\log$ (price)

$\begin{array}{lc}\mathrm{N} & 1.002 \\ \text { Adjusted- } R^{2} & 0.789 \\ \mathrm{~F} & 409.40 \\ p \text {-value } & 0.000 \\ \text { Mean VIF } & 2.06 \\ \text { Max VIF } & 3.88 \\ \text { Durbin-Watson } & 1.39\end{array}$

We focus only on the season variable ('time period') as the main goal of this paper, the other variables serving to control it. The period of the year's effect on final price (taking August as the reference) leads us to conclude that there is a significant difference in prices. The only exception is July in the case of second home rentals (that is, there is no significant price difference regarding August as indicated in Tables 5 and 6 above). Previous stepwise regressions with the same estimation but without the 'time period' variable drop the adjusted $R^{2}$ in both cases until reaching 0.5 . This means that the role of seasonality is significantly important to be included in the final estimation.

In order to interpret these results, we created a seasonality price index using the significant aforementioned coefficients for each accommodation type. This index is computed as $100 \cdot e^{\text {month }_{i}}$, where ${ }^{\text {month }_{i}}$, the estimate of the parameter, is linked with the month $i$ in Tables 5 (hotels) and 6 (second home rentals).

Price indexes in Table 7 confirm the results described in the previous section. Thus, after controlling for the different characteristics, price seasonality is 
Table 7. Hotel and second home seasonality price index.

\begin{tabular}{lcc}
\hline Month & Hotels & Second home rentals \\
May & 63.73 & 69.24 \\
June & 71.53 & 71.86 \\
July & 82.49 & $97.70(\mathrm{~ns})$ \\
August & 100 & 100 \\
September & 72.04 & 73.29 \\
October & 63.72 & 70.90 \\
\hline
\end{tabular}

Note: $\mathrm{ns}=$ not significant.

higher in hotels than in second home rentals. As a matter of fact, price differences between shoulder months (May and October) and August are higher for hotels (which are $36 \%$ cheaper) than for second home rentals (30\% cheaper).

Another remarkable result appears when comparing July and August. As argued, there is no significant difference in prices for second home rentals, but there is a $17.5 \%$ price difference for hotels. Finally, we also identify similar results for June and September. There is a $26.71-28.47 \%$ price difference in percentage points during these two months compared to August in both accommodation options. Figure 1 illustrates the price index seasonality patterns.

\section{Discussion and tourist strategies}

\section{Hypotheses to contrast industry behaviour}

The analysis of seasonality has focused on the supply side in terms of pricing tactics enacted by tourist accommodation managers. In line with Hypotheses 1 and 3, we can conclude that there are significant differences in prices between hotels and second homes using three seasonality indicators (Hypothesis 1) and when using hedonic methods that permit a quantitative price difference analysis (Hypothesis 3). As previously noted, hotels exhibit a much sharper summer peak than second home rentals. Comparing the peak period (August) and shoulder periods (May and October), we see that price differences are higher in hotels. There is no difference when June and September are compared to August. We can also conclude that in second home rentals there are two peak months (July and August), compared to one for hotels (August).

According to Hypothesis 2, we can conclude that the role played by the 'time period' factor is important in determining the final price of accommodation, reaching significant results in regressions with a high adjusted $R^{2}$ (around 0.8) and controlling for other variables. Obviously, it is not only the time period (from May to October) that can affect the final price of tourist accommodation. These other variables (shown in Tables 5 and 6) also contribute to explain the overall price.

These findings are interesting when comparing strategies in pricing policy and yield management across types of tourist accommodation. There are reasons from both the demand and supply sides that elucidate the different price patterns. From the demand point of view, we can talk about tourist profiles 


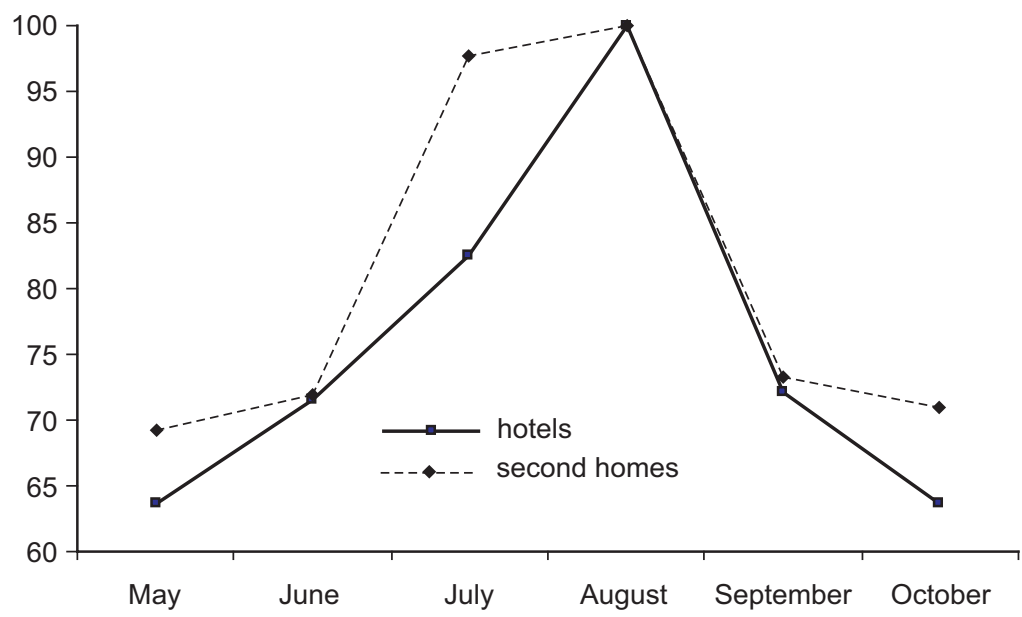

Figure 1. Monthly price index for hotels and second home rentals. Note: August is used as a reference $=100$.

and length of stay, both of which can clarify whether there is steadier demand in second homes during shoulder periods compared to hotels, and how this might be reflected in the final market price. From the supply side, the number of services offered and qualitative aspects (distance to the beach, star rating and so on), as well as the different cost structure between hotels and second homes, could also be a reason that explains pricing behaviour.

To sum up, the reasons explaining industry behaviour from the demand side ( 1 and 2), in terms of market structure (3) and the supply side ( 4 and 5) may be as follows:

1. Tourist profile and preferences. This may be a decisive variable in determining different price structures. Variables such as income level, age, occupation, individual or group trip (singles, friends, couples or families) and a 'likedislike' analysis regarding accommodation and the environment could be examined. Every accommodation type has its own customer profile.

2. Length of stay. Hotels seem to welcome tourists for shorter periods of time, albeit more frequently than second home rentals. This demand pattern can affect seasonal behaviour and, by extension, pricing policy (Butler, 2001).

3. Commercialization channel. This is another element to take into account. The role of intermediaries in each market could affect the final price, depending on the range of options available when selecting the final accommodation (Internet, travel agencies and tour operators).

4. Accommodation quality and services. Differences in quality and services offered to tourists could also determine price differences between accommodation types. According to Hudson (2008) and Shy (2008), a type of premium pricing policy (steadier prices throughout the year) could be applied in the accommodation market due to differences in the quality of the services offered. 
5. Cost structure. Hotels seem to bear higher fixed and variable costs than second homes. This is a possible determinant of pricing strategy (the price needed to cover the costs).

\section{Tourist strategies in the area}

The results presented in this paper may pave the way for identifying new strategies to enhance revenues among tourism stakeholders. We can break down our analysis into several points that highlight pricing strategies and actions to smooth seasonality, strategies and actions that can be adopted by policy makers ( 1 and 2), managers (3), and policy makers and managers combined (4, 5 and 6):

1. The proliferation of second homes in this area as well as in other regions has potential benefits that may smooth seasonal trends. A good public incentive system, through housing tax discounts or other options, could encourage second home owners to stay in them permanently during offseason periods. A good target market is retired owners. This is also a sustainable and more efficient option in economic terms (a good return on investment for public expenditure on second homes (street maintenance, lighting and cleaning) and, of course, more revenues (public and private) for the municipality. Similar strategies could encourage hotels to open during off-season periods.

2. A limited number of licences for hotels and second home rentals could balance the negative effects of seasonality and modify the market structure and final price. An improvement in public infrastructures could also be a factor in attracting tourists during non-peak periods.

3. Tourist pricing tactics do not require a one-size-fits-all measure to reduce seasonality in the accommodation market. It seems reasonable that every accommodation option has its own tactics because of the variety in tourism - in terms of supply (the services offered) and demand (different profiles). However, a mixed strategy is necessary between accommodation types and the complementary offering (culture, sports, festivals, specific events, etc), because the tourist product is a full package. Thus, a mixed pricing policy should also be appropriate.

4. Following on from the above point, local policy makers and managers could develop and promote more activities as a complementary offer to increase demand, especially during shoulder periods (May, September and October).

5. Because of calendar restrictions, these activities should coincide with the few bank holidays available during shoulder and off-season periods. They should target local tourists and close-by foreign tourists for short trips. This is an option for compensating for the possible lack of the key attraction of good weather during the off-peak period (in sun-and-beach destinations).

6. Another strategy would be to promote different tourist packages targeted at specific profiles that have more flexibility in their calendar throughout the year. These groups could include retired people, college students, selfemployed workers, top professional sports players and senior business managers. 


\section{Conclusions and further research}

The analysis of seasonality is generally focused on the demand side, while how to overcome problems for local residents, policy makers and managers remains an important issue. Sun-and-beach destinations like the Costa Brava in Spain face historically high demand during a couple of peak periods in the summer. This paper has contributed to the analysis of the supply side, examining price evolution during the entire tourist season. Moreover, an analytical comparison of two different accommodation options, such as hotels and second home rentals, has not previously been presented. Both these factors allow us to improve on the results of previous studies which examine only the overall tourist sector from either the demand or the supply side.

We applied various statistical analyses to a database of 144 hotels and 1,002 second homes on the Costa Brava. First, we measured seasonality using three unit-free indicators. We can confirm that hotels are more seasonal than second homes in all of them. Second, a hedonic price methodology was considered a key and very little studied solution to analyse price seasonality controlling by other variables that influence price, such as star rating, characteristics and distance to the beach. In addition, it contributes to the creation of a price index that permits us to compare seasonality patterns by type of accommodation.

The main results from the regressions carried out confirm that hotels have a sharper summer peak price than second home rentals. Prices in May and October are lower in hotels than second homes, both compared to prices in August. In June and September, they have similar pricing trends compared to August. We can also conclude that second homes have two peak periods (July and August), while hotels have one (August).

In terms of future research, and in order to identify differences in pricing tactics, it would be interesting to explore aspects of the demand side: demand profiles and length of stay. In this regard, interviews or questionnaires in a qualitative research study on the area (Costa Brava) might serve to reach some conclusions. On the supply side, the quality of the offer (an in-depth evaluation of accommodation establishments' star rating) and a capital cost structure (fixed and variable costs) might be helpful. The commercialization channel is another element that could affect pricing policy.

Policy makers and managers can also set individual and mixed pricing strategies to smooth seasonality in shoulder and off-season periods. Attention might be concentrated on overcoming calendar restrictions, improving the complementary offering and promoting different strategies for different focus groups. Second homes can also be occupied during off-season periods given an appropriate public incentive system.

Finally, extending this analysis to other important types of lodgings, such as campsites and rural houses, could provide a complete cross-section analysis of the accommodation industry. This would also be very useful for tourism marketing, in terms of developing different strategies for each sector in the Costa Brava.

\section{References}

Aguiló, E., and Sastre, A. (1984), 'La Medición de la Estacionalidad del Turismo: el caso de Baleares' ['Tourist seasonality measurement: the Balearic islands case'], Estudios Turísticos, No 81, pp 79-88. 
Albacete, C.A., Fuentes, M., and Llorens-Montes, J. (2007), 'Service quality measurement in rural accommodation', Annals of Tourism Research, Vol 34, No 1, pp 45-65.

Albadalejo, I.P., and Díaz, M.T. (2005), 'Rural tourism demand by type of accommodation', Tourism Management, Vol 26, No 6, pp 951-959.

Albadalejo, I.P., and Díaz, M.T. (2009), 'Tourist preferences for rural house stays: evidence from discrete choice modelling in Spain', Tourism Management, Vol 30, No 6, pp 805-811.

Ashworth, J., and Thomas, B. (1999), 'Patterns of seasonality in employment in tourism in the UK', Applied Economic Letters, No 6, pp 735-739.

Barke, M., and France, L. (1986), 'Tourist accommodation in Spain 1971-1981', Tourism Management, Vol 7, No 3, pp 181-196.

Bar-on, R. (1999), 'The measurement of seasonality and its economic impacts', Tourism Economics, Vol 5, pp 437-458.

Baum, T., and Lundtorp, S. (2001), 'Seasonality in tourism: an introduction', in Baum, T., and Lundtorp, S., eds, Seasonality in Tourism, Pergamon, Oxford, pp 1-4.

Bover, O., and Velilla, P. (2002), 'Hedonic house prices without characteristics: the case of new multiunit housing', Working Paper Series, No 117, European Central Bank, Frankfurt.

Butler, R.W. (2001), 'Seasonality in tourism: issues and implications', in Baum, T., and Lundtorp, S., eds, Seasonality in Tourism, Pergamon, Oxford, pp 5-21.

Butler, R.W. (1994), 'Seasonality in tourism: issues and problems', in Seaton, A., Jenkins, C., Wood, R., Dieke, P., Bennet, M., Maclellan, L., and Smith, R., eds, Tourism: the State of the Art, Wiley, Chichester.

Capó Parrilla, J., Riera Font, A., and Rosselló Nadal, J. (2007), 'Accommodation determinants of seasonal patterns', Annals of Tourism Research, Vol 34, No 2, pp 422-436.

Cuccia, T., and Rizzo, I. (2011), 'Tourism seasonality in cultural destinations: empirical evidence from Sicily', Tourism Management, Vol 32, No 3, 589-595.

Espinet, J.M., Sáez, M., Coenders, G., and Fluvià, M. (2003), 'Effect on prices of the attributes of holiday hotels: a hedonic prices approach', Tourism Economics, Vol 9, No 2, pp 165-177.

Fernández-Morales, A. (2003), 'Decomposing seasonal concentration', Annals of Tourism Research, Vol 30, No 4, pp 942-956.

Gil-Alana, L.A., Pérez de Gracia, F., and Cunado J. (2004), 'Seasonal fractional integration in the Spanish Tourism Quarterly Time Series', Journal of Travel Research, No 42, pp 408-414.

González, P., and Moral, P. (1996), 'Analysis of tourism trends in Spain', Annals of Tourism Research, Vol 23, No 4, pp 739-754.

González, P. and Moral, P. (1995), 'An analysis of the international tourism demand in Spain', International Journal of Forecasting, Vol 11, No 2, pp 233-251.

Guizzardi, A., and Mazzocchi, M. (2010), 'Tourism demand for Italy and the business cycle', Tourism Management, No 31, pp 367-377.

Haroutunian, S., Mitsis, P., and Pashardes, P. (2005), 'Using brochure information for the hedonic analysis of holiday packages', Tourism Economics, Vol 11, No 1, pp 69-84.

Hudson (2008), Tourism and Hospitality Marketing: a Global Perspective, Sage, London.

Jang, S. (2004), 'Mitigating tourism seasonality: a quantitative approach', Annals of Tourism Research, Vol 31, No 4, pp 819-836.

Jeffrey, D., and Barden, R.R.D. (2001), 'An analysis of the nature, causes and marketing implications of seasonality in the occupancy performance of English hotels', in Baum, T., and Lundtorp, S., eds, Seasonality in Tourism, Pergamon, Oxford, pp 119-140.

Krakover, S. (2000), 'Partitioning seasonal employment in the hospitality industry', Tourism Management, Vol 21, No 5, pp 461-471.

Koenig, N., and Bischoff, E. (2003), 'Analyzing seasonality in Welsh room occupancy data', Annals of Tourism Research, Vol 31, No 2, pp 374-392.

Kulendran, N., and Wong, K.K.F. (2005), 'Modeling seasonality in tourism forecasting', Journal of Travel Research, Vol 44, No 2, pp 163-170.

Lundtorp, S. (2001), Measuring Tourism Seasonality, in Baum, T., and Lundtorp, S., eds, Seasonality in Tourism, Pergamon, Oxford, pp 23-50.

Lundtorp, S., Rassing, C. R., and Wanhill, S. (2001), Off-Season Is No Season: the Case of Bornholm, in Baum, T., and Lundtorp, S., eds, Seasonality in Tourism, Pergamon, Oxford, pp 89-108.

Mayorga-Toledano, M.C., and Fernández-Morales, A. (2008), 'Seasonal concentration of the hotel demand in Costa del Sol: a decomposition by nationalities', Tourism Management, Vol 29, No 5, pp 940-949. 
Palmquist, R., and Halverson, R. (1980), 'The interpretation of dummy variables in semilogarithmic equations', American Economic Review, Vol 70, No 3, pp 474-475.

Pearce, D.G., and Grimmeau, J. (1985), 'The spatial structure of tourist accommodation and hotel demand in Spain', Geoforum, Vol 16, No 1, pp 37-50.

Rigall-I-Torrent, R.,. and Fluvià, M. (2007), 'Public goods in tourism municipalities - formal analysis, empirical evidence and implications for sustainable development', Tourism Economics, Vol 13, No 3, pp 361-378.

Rigall-I-Torrent, R., and Fluvià, M. (2010), 'Managing tourism products and destinations embedding public good components: a hedonic approach', Tourism Management, Vol 32, No 2, 244-255.

Rosselló, J., Riera, A., and Sansó, A. (2004), 'The economic determinants of seasonal patterns', Annals of Tourism Research, Vol 31, No 3, pp 697-711.

Saló, A., and Garriga, A. (2011), 'Second home rental market: a hedonic analysis of the effect of different characteristics and a high-market-share intermediary on price', Tourism Economics, Vol 17, No 5, pp 1017-1033.

Sinclair, T., Clewer, A., and Pack, A. (1990), 'Hedonic prices and the marketing of package holidays: the case of tourism resorts in Malaga', in Ashworth, G.J., and Goodall, B., eds, Marketing Tourism Places, Routledge, London, pp 85-103.

Shy, O. (2008), How to Price: a Guide to Pricing Techniques and Yield Management, Cambridge University Press, New York.

SooCheong, J. (2004), 'Mitigating tourism seasonality: a quantitative approach', Annals of Tourism Research, Vol 31, No 4, pp 819-836.

Sutcliffe, C.M.S., and Sinclair, M.T. (1980), 'The measurement of seasonality within the tourist industry: an application to tourist arrivals in Spain', Applied Economics, Vol 12, No 4, pp 429.

Thrane, C. (2005), 'Hedonic price models and sun-and-beach package tours: the Norwegian case', Journal of Travel Research, Vol 43, No 2, pp 302-308.

Wanhill, S.R.C. (1980), 'Tackling seasonality: a technical note', Tourism Management, Vol 1, No 4, pp 243-245.

Yacoumis, J. (1980), 'Tackling seasonality: the case of Sri Lanka', Tourism Management, Vol 1, No 2, pp 84-98. 